\title{
Comparative study of methods using Hoechst reagent and polychromatic staining for the detection of mycoplasma- like organisms in plants
}

Marie-Thérèse COUSIN \& Pascale JOUY

I.N.R.A., Station de Pathologie végétale, Route de Saint-Cyr, F 78000 Versailles

HoECHST reagent, a DNA-specific fluorochrome, was used on serial sections of plant material which had been fixed, paraffin embedded, then deparaffinized. This procedure, which allows conservation of the material and observation of $7 \mu \mathrm{m}$ thick serial sections, could be used for the detection of low number of M.L.os and the study of their development in the plant.

In resin-embedded material, polychromatic staining of $0.5-1 \mu \mathrm{m}$ thick sections, in particular with thioninacridine orange, allowed much more accurate M.L.o. detection than the monochromatic staining commonly used.

Additional key words : Light microscopy, fluorochrome, paraffin, resin, semi-thin section, thionin, acridine orange, methylene blue, azure $A$, safranin.

Etude comparative de méthodes utilisant le réactif de Hoechst et les colorations polychromatiques pour la détection des mycoplasmes chez les végétaux.

Le réactif de HOECHST, fluorochrome spécifique de l'ADN, a été utilisé sur coupes sériées de matériel végétal fixé, inclus dans la paraffine, puis déparaffiné. Ce procédé qui permet la conservation du matériel et l'obtention de coupes sériées de $7 \mu \mathrm{m}$ d'épaisseur, rend possible la détection d'un petit nombre de mycoplasmes et l'étude de leur évolution dans la plante.

Sur matériel inclus dans les résines, les colorations polychromatiques (thionine - acridine orange en particulier) de coupes de 0,5 à $1 \mu \mathrm{m}$ d'épaisseur, permettent de repérer les mycoplasmes avec beaucoup plus de précision que les colorations monochromatiques couramment utilisées jusqu'ici.

Mots clés additionnels : Microscopie photonique, fluorochrome, paraffine, résine, coupe semi-fine, thionine, acridine orange, bleu de méthylène, azur $A$, safranine.

\section{INTRODUCTION}

It is still quite difficult to identify plant mycoplasma diseases. The indexing methods using grafting, dodder or insect vectors are tedious and cannot be used in every case. Due to spontaneous recovery, tests using derivatives of tetracycline are sometimes difficult to apply. Specific and high titer sera are difficult to obtain with M.L.Os. Transmission electron microscopy (T.E.M.), which is a cumbersome technique, permits only the investigation of a restricted area of the plant. Light microscopy methods under normal or fluorescent light are accessible to any laboratory. Recent advances in their specificity and accuracy have contributed to the wider use of such methods.
Initial work on the detection of yellows diseases was conducted using fluorescence microscopy without fluorochrome (COUSIN \& GRISON, 1966 ; COUSIN et al., 1968) or with fluorochromes non-specific for DNA or callose (CARLE, 1965). Altered areas could thus be detected in the phloem of the plant. However, no accurate information was provided on the presence of mycoplasmas. Use of aniline blue, a fluorochrome specific for callose at pH8 (ESCHRICH \& CURRIER, 1964 ; HIRUKI \& SHUKLA, 1973) showed this polysaccharide accumulation of on the walls of sieve tubes, within the intine of altered pollen grains, or in free state inside the pollen sacs (COUSIN, 1979, 1980).

Recent progress on DNA-specific fluorochromes such as D.A.P.I. (4-6 Diamidino 2 phenylindole) and 
HOECHST reagent (bis-benzimidazole derivate) has raised increased interest in fluorescence microscopy. These fluorochromes were first used on animal cells (RUSSEL et al., 1975 ; BONISSOL et al., 1978), then on plant material (SEEMÜLLER, 1976 ; CAZELLES, 1978 ; DOSBA \& LANSAC, 1982 ; COUSIN \& JOUY, 1983a, $b$ ).

Other DNA-specific fluorochromes (PETZOLD \& MARWITZ, $1979 a, b, c)$ can be used but provide no additional information as D.A.P.I. and HOECHST.

\section{METHODS AND RESULTS}

\section{A. Utilization of HoECHST reagent}

We compared the results obtained under blue and ultraviolet light on sieve tubes isolated by pectinase, on fresh or fixed plant material cut by freezing microtome and finally on material embedded in paraffin after fixation and dehydration. For the present study, we selected Catharanthus roseus both as a control and affected by stolbur.

UV light permitted easier observation than blue light. As a result, major additional fluorescence can be removed. Nevertheless, blue-light observation is complementary because it allows the better localization of fluorescent areas in all plant tissues.

The isolation of sieve tubes by pectinase, as described by CAZELLES (1978), was conducted on fresh material or material fixed by $3 \%$ glutaraldehyde in cacodylate buffer $0.1 \mathrm{M}$ at $\mathrm{pH} 7.2$. This procedure gives more or less satisfactory results depending on the origin of the pectinase used.

The procedure of freezing sections of fresh or fixed material gave excellent results, confirming the work of DOSBA \& L.ANSAC (1982). Fixatives derived from formalin should be discarded, whereas Carnoy's fluid as well as $3 \%$ glutaraldehyde in cacodylate buffer $0.1 \mathrm{M}$ at $\mathrm{pH} 7.2$ proved to be satisfactory. This procedure, that can be handled more easily than Feulgen staining (KARTHA et al., 1975), is much more accurate. Isolated particles can be detected.

Finally, similar fluorescence was obtained on material fixed as previously described, dehydrated, embedded in paraffin, then deparaffinized and gradually rehydrated (plate 1 ). The previously mentioned fixatives were satisfactory. However, glutaraldehyde seemed to preserve the tissues better than Carnoy's fluid. This fincling is in agreement with the results of FEDER \& O'BRIEN (1968) who recommend the use of non-coagulant fixatives such as osmium tetroxide, acrolein, glutaraldehyde or formaldehyde. The accuracy of the results obtained on paraffin-embedded material was improved by thinner sections ( 7 to $10 \mu \mathrm{m})$ and by the possibility of obtaining serial sections. Isolated (a), concentrated (b) and degenerated (c) MLOs could be detected (plate 1). In addition, the material could be permanently preserved.

However, the procedures based on HOECHST reagent and D.A.P.I. showed some limitations. They provided information solely on DNA, but not on the nature of the pathogen (mycoplasma, bacterium or DNA virus). Besides, they were not suitable for material embedded in the resins commonly used in T.E.M. such as epon, araldite or Spurr's mixture. Adjacent sections fixed simultaneously can be observed successively under light and electron microscopy (DOSBA \& LANSAC, 1982), but the investigation cannot be carried on within one block. Therefore, it seems that histochemical procedures on semi-thin sections should be improved simultaneously with the above procedures using fluorescence microscopy.

\section{B. Use of polychromatic stains for improving staining procedures on semi-thin sections (COUSIN \& JOUY, 1983)}

Usually, the presence of resin is considered to be a major obstacle to the penetration of histochemical stains. Unfortunately, the resin can be removed only by procedures that denature the cell. Satisfactory results obtained with such stains on semi-thin sections embedded in resin are being increasingly reported, whereas research work on the removal of resins does not seem to produce the positive results expected.

We selected two staining procedures which proved to be effective on semi-thin sections embedded in resin : first, thionin and acridine orange (PAUL, 1980) and secondly, methylene blue-azure $\mathrm{A}$ and safranin (WARMKE \& LEE, 1976).

\section{Thionin and acridine orange (PAUL, 1980)}

\section{Solution $A$ : Thionin}

Thionin ........................ $0.5 \mathrm{~g}$

Distilled water $\ldots \ldots \ldots \ldots \ldots \ldots \ldots \ldots, 200 \mathrm{ml}$

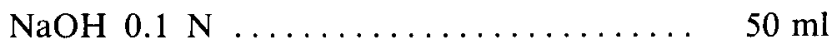

$90 \%$ ethanol ................... $250 \mathrm{ml}$

\section{Solution B : Acridine orange}

Acridine orange ................. $6.25 \mathrm{~g}$

Distilled water .................. $200 \mathrm{ml}$

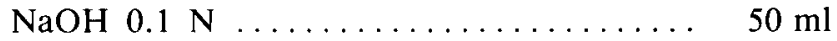

Staining was carried out using warming plate at $45{ }^{\circ} \mathrm{C}$. The slide was covered with solution $\mathrm{A}$ for $10 \mathrm{~min}$, rinsed with distilled water, dried on the warming plate, and then covered with solution B for $2 \mathrm{~min}$. Finally, the section was mounted in the resin that had been previously used for embedding the samples.

\section{Methylene blue-azure $A$ and safranin (WARMKE \& LEE, 1976)}

Solution $A$ : Methylene blue-azure $A$

Methylene blue .................. $0.13 \mathrm{~g}$

Azure A ....................... $0.02 \mathrm{~g}$

Glycerol ........................ $10 \mathrm{ml}$

Methanol ...................... $10 \mathrm{ml}$

Phosphate buffer $0.1 \mathrm{M}, \mathrm{pH} 6.9 \ldots \ldots \ldots .30 \mathrm{ml}$

Distilled water .................. $50 \mathrm{ml}$

Solution B : Safranin

Safranin $\ldots \ldots \ldots \ldots \ldots \ldots \ldots \ldots \ldots, 0.1 \mathrm{~g}$

Tris buffer $0.2 \mathrm{M}$, pH $9.0 \ldots \ldots \ldots \ldots \ldots, 100 \mathrm{ml}$

The slides were dipped in solution A for $30 \mathrm{~min}$ at $60{ }^{\circ} \mathrm{C}$, rinsed thoroughly with distilled water, immersed in solution $\mathrm{B}$ at $60^{\circ} \mathrm{C}$, rinsed with running water, then with distilled water and dried on the warming plate set at $60{ }^{\circ} \mathrm{C}$. After 3 successive xylene baths, 

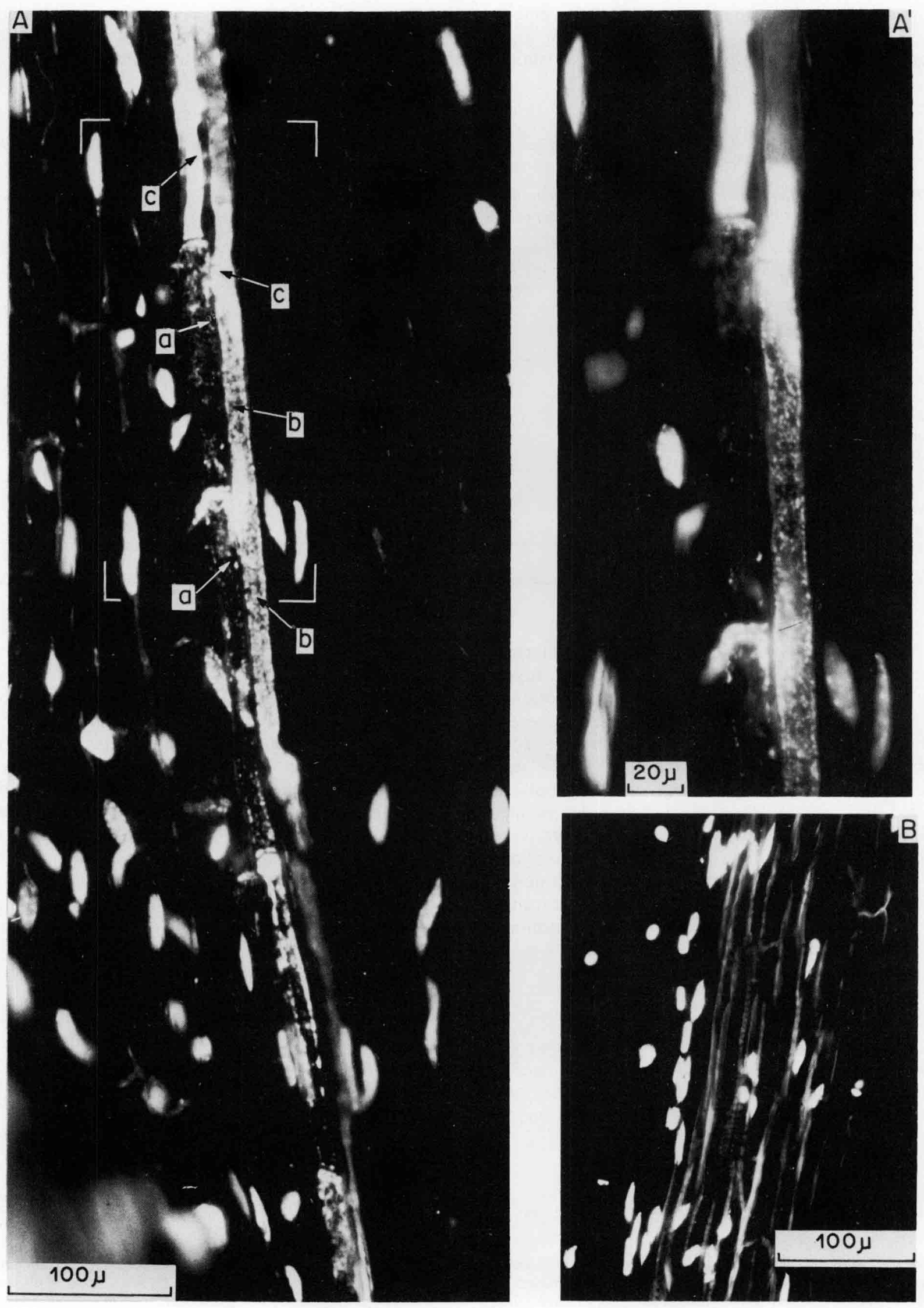

Plate I

Longitudinal sections of sieve tubes from phloem fixed and embedded in paraffin. Sections stained with HOECHST reagent after deparaffinizing.

(A) Stolbur: mycoplasma-infected sieve tubes. Isolated (a), concentrated (b) and degenerated (c) mycoplasmas can be detected. (A') Detail

(B) Control.
Coupes longitudinales de tubes criblés obtenues à partir de tissus libériens fixés et inclus dans la paraffine. Les coupes sont colorées par le réactif de HOECHST après élimination de la paraffine.

(A) Stolbur: tubes criblés infectés par des mycoplasmes. Des mycoplasmes isolés (a), concentrés (b), et dégénérés (c), peuvent être décelés.

(A') Détail

(B) Témoin. 
they were mounted in the same resin used for embedding.

Both thionin and methylene blue-azure A stained
MLO, nucleoplasm, nucleolus and cytoplasm differentially, whereas acridine orange and safranin allowed the detection of wall constituents (table 1).

TABLE 1

Colour reactions of different forms of MLos and host cell constituents with mono and polychromatic stains, using 0.5-1 $\mu m$ semi-thin and resin embedded sections.

Observations de différentes formes de M.t.o et d'éléments cellulaires de la plante-hôte, à la suite de colorations monochromatiques et polychromatiques réalisées sur des coupes semi-fines de 0,5-I l m d'épaisseur dans les résines.

\begin{tabular}{|c|c|c|c|c|}
\hline \multirow{2}{*}{\multicolumn{2}{|c|}{ Stains }} & \multirow[t]{2}{*}{ Monochromatic } & \multicolumn{2}{|c|}{ Polychromatic } \\
\hline & & & $\begin{array}{c}\text { Thionin-acridine } \\
\text { orange }\end{array}$ & $\begin{array}{l}\text { Methylene blue } \\
\text { azure A, safranin }\end{array}$ \\
\hline $\begin{array}{l}\text { Typical isolated (a) } \\
\text { and concentrated (b) } \\
\text { M.L.o. } \\
\text { degenerated (c) } \\
\text { M.L.o. }\end{array}$ & & dark red & light purple & blue black \\
\hline $\begin{array}{l}\text { Nucleoplasm } \\
\text { Nucleolus } \\
\text { Cytoplasm }\end{array}$ & & $\begin{array}{l}\text { light pink } \\
\text { dark pink } \\
\text { pink }\end{array}$ & $\begin{array}{l}\text { light purple } \\
\text { blue purple } \\
\text { purple }\end{array}$ & $\begin{array}{l}\text { purple } \\
\text { blue purple } \\
\text { dark purple }\end{array}$ \\
\hline Cellulose & & red & yellow & red \\
\hline
\end{tabular}

In $0.5-1 \mu \mathrm{m}$ thick semi-thin sections of material embedded in resin (epon and Spurr's mixture), mycoplasmas could be detected individually and followed in different stages (plate II). In one section several types of mycoplasmas could be observed : some MLOs (a) were scattered along the walls of the sieve tubes. Others (b) occurred in large numbers, but still scattered and individually distinct. Some degenerated MLOs (c) formed more intensely stained clusters.

Observations are summarized in table 1 that shows the advantage of polychromatic stains (thioninacridine orange and methylene blue-azure A-safranin) as compared to monochromatic stains commonly used on semi-thin sections.

\section{CONCLUSION}

Fluorescence microscopy has made considerable progress over recent years. Presently it is the most rapid and specific method for identifying myco- plasmas under light microscopy. Using this procedure on sections embedded in paraffin, it is now possible to store the samples and to improve the image obtained due to the thinness of the sections.

The present results concerning the use of polychromatic stains on semi-thin sections represent a preliminary step toward improving the methods devised for the examination of material embedded in resin, although these methods are more timeconsuming than those using fluorescence and are not DNA-specific. They permit the observation of individual mycoplasmas, which was difficult with monochromatic stains, and they provide information suitable for confirming by electron microscopy. Such methods should be accessible to any laboratories with microtomes capable of sectioning either paraffin or resin. The blocks might then be sent on to electron microscopy laboratories for final identification. Accepted November 22, 1983.

\section{REFERENCES}

Bonissol C., Gilbert M., Ivanova L. M., 1978. Valeur de la technique de coloration d'ADN pour le dépistage de contamination des cultures cellulaires par les mycoplasmes. Ann. Microbiol. (Inst. Pasteur), 129 B, 24.5-265.

Carle P., 1965. Fluoroscopie des symptômes histologiques de la flavescence dorée de la vigne. Application à la détection rapide des lésions précoces sur cépage sensible (Baco 22A). Ann. Epiphyt., N.H.S., 16, 73-85.

Cazelles O., 1978. Mise en évidence par fluorescence des mycoplasmes dans les tubes criblés intacts isolés des plantes infectées. Phytopathol. Z., 91, 314-319.
Cousin M. T., 1979. Apparition d'une substance callosique néoformée dans l'intine de grains de pollen de Vinca rosea (Apocynaceue) atteinte de stolbur (mycoplasmose). C. R. Acad. Sci., 289, 1339-1342.

Cousin M. T., 1980. Changes induced by mycoplasma-like organisms (MlO), etiologic agents of the stolbur disease in the different tissues of the anther of Vinca rosea L. (Apocynaceae). Grana, 19, 99-125.

Cousin M. T., Grison C., 1966. Premières observations concernant une fluorescence anormale dans le liber interne de plusieurs solanacées infectées par le stolbur et d'une apocynacée atteinte de stolbur. Ann. Epiphvt., N. H.S., 17, 93-98. 


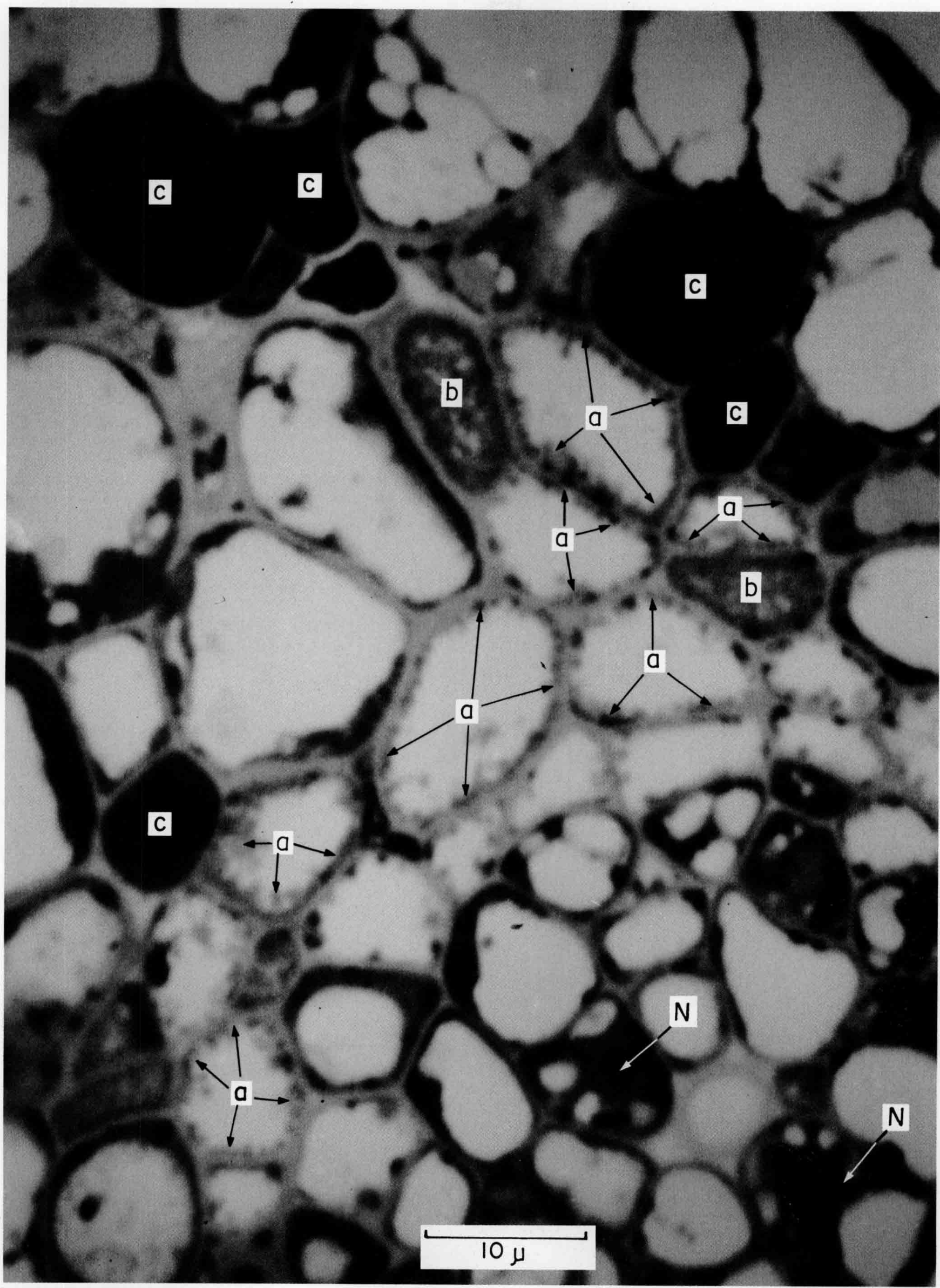

Plate II

Transverse sections of sieve tubes from phloem fixed and embedded in epon sections stained with thionin-acridine orange, without removing resin.

Stolbur mycoplasmas: isolated (a) and concentrated (b) mycoplasmas are stained light purple, and degenerated (c) mycoplasmas very dark purple. The cellulose cell wall stains yellow. $N$ nuclei.
Coupes transversales de tubes criblés obtenues à partir de tissus libériens fixés et inclus dans l'épon. Les coupes sont colorées par la thionine et l'acridine orange, sans élimination de la résine.

Mycoplasmes responsables du stolbur. Les mycoplasmes isolés (a) et concentrés (b) sont colorés en mauve clair, les mycoplasmes dégénérés (c) en violet très foncé, la paroi cellulaire cellulosique en jaune. $N$ (noyaux) 
Cousin M. T., Grison C., Decharme M., 1968. Etude comparée de plusieurs types de flétrissements de solanacées. Polyphagie du stolbur. Histologie. Ann. Epiphyt.; N.H.S., 19, 121-140.

Cousin M. T., Jouy P., 1983a. Différents processus d'utilisation du réactif de HoEchST, fluorochrome du DNA, en vue du diagnostic des mycoplasmoses végétales. Avantages et limites. Agronomie, 3 (5), 496-497 (23e Colloq. Soc. Fr. Phytopathol., Versailles 21-22 octobre 1982, res. comm.).

Cousin M. T., Jouy P., 1983b. Recherches en vue de l'amélioration des techniques de coloration des mycoplasmes sur coupes semi-fines. Utilisation de colorants polychromatiques: thionineacridine orange et bleu de méthylène azur A-safranine. Agronomie,

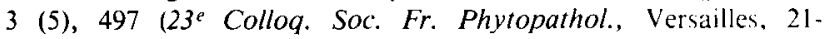
22 octobre 1982, res. comm.).

Dosba F., Lansac M., 1982. Détection des organismes de type mycoplasme chez les especes fruitieres au moyen du test DAPI. $2^{e}$ Colloq. Rech. Fruitière, Bordeaux, 247-257.

Eschrich W., Currier H. B., 1964. Identification of callose by its diachrome and fluochrome reactions. Stain Technology, 39, 303307.

Feder N., O'Brien T. P., 1968. Plant microtechnique : some principles and new methods. Annu. J. Bot, 55 (1), 123-142.

Hiruki C., Shukla P., 1973. Mycoplasma-like bodies associated with witches' broom of bleeding heart. Phytopathology, 63, 88-92.

Kartha K. K., Cousin M. T., Ruegg E. F., 1975. A light microsco- pic detection of plant mycoplasma infection by Feulgen staining procedure. Indian Phytopathol., 28 (1), 51-56.

Paul R. N., 1980. The use of thionin and acridine orange in staining semi-thin sections of plant material embedded in epoxy resin. Stain Technology, 55 (4), 195-196.

Petzold H., Marwitz R., 1979 a) Der fluoreszenzmikroskopische Nachweis, Mycoplasma-ähnlichen Organismen nach der Feulgen Reaktion mit Auramin $\mathrm{O}$ als Schiffsches-reagenz. Z. Pflanzenkr. Pflanzenschutz,' 86 (9-10), 577-583.

Petzold H., Marwitz R., 1979 b) Uber die Verwendbarkeit des Fluoreszenzfarbstoffes $\mathrm{N}, \mathrm{N}$ ' diäthylpseudoisocyaninchlorid zum Nachweis von mykoplasmaähnlichen Organismen. Z. Pflanzenkr. Pflanzenschutz, 86 (11), 670-674.

Petzold H., Marwitz K., 1979 c) Fluoreszensmikroskopische Untersuchungen zum Nachweis von mykoplasmaähnlichen Organismen mittels Berberinsulfat. Z, Pflanzenkr. Pflanzenschutz, 86 (12), 745-750.

Russell W. C., Newman C., Williamson D. H., 1975. A simple cytochemical technique for demonstration of DNA in cells infected with mycoplasmas and viruses. Nature, 253, 6, 461-462.

Seemuller E. T., 1976. Fluoreszenzoptischer Direktnachweis von mykoplasmaähnlichen Organismen im Phloem pear-decline- und I riebsuchtkranker Bäume. Phytopathol. Z., 85, 368-372.

Warmke H. E., Lee S. L. J., 1976. Improved staining procedures for semi-thin epoxy sections of plant tissues. Stain Technology, 51 (3), 179-185. 